\title{
The changing face of rheumatism
}

\author{
JAMES W. KERR \\ From the Medical Research Council Atheroma Unit, Western Infirmary, Glasgow
}

In recent years there has been a decline in the incidence of rheumatic fever and this has been accentuated since antibiotics became freely available for the treatment of throat infections. The rheumatic fever committee of the Royal College of Physicians reported in 1957 that the illness appeared less severe than in the past and that the immediate mortality was less. Despite this, it would be a mistake to think that acute rheumatism was not a commonly occurring condition. This presentation is a review of the incidence and some of the clinical and laboratory findings in acute rheumatism as observed in the M.R.C. Atheroma Unit of the Western Infirmary during the past seven years.

\section{INCIDENCE AND DIAGNOSIS}

Most studies of acute rheumatism have been designed to measure the therapeutic response to some form of treatment or to compare the incidence of carditis in comparable groups. Thus the criteria for inclusion as a case of acute rheumatism in such a trial have been designed to exclude the borderline or doubtful case. In this series, the criteria of Jones (1944) as modified for the cooperative clinical trial in 1955 and 1960 have been used (Table I). The criteria are in two groups, major and minor, and the diagnosis requires either one major and two minor, or two major and one minor. Although such selection is essential if clinical material from different centres is to be compared, it is easy to overlook many cases of acute rheumatism and the true incidence may be obscured.

Table II shows the number of patients with acute rheumatism admitted to one hospital in Glasgow between 1954 and 1961. During this period 159

\section{TABLE II}

PATIENTS WITH ACUTE RHEUMATISM ADMITTED TO WESTERN INFIRMARY 1954-61

\begin{tabular}{lc} 
Accepted & Rejected \\
\hline $139+20^{1}=159$ & 107 (unknown criteria)
\end{tabular}

M.R.C. Unit
Other wards

${ }^{1}$ Twenty patients under 12 years of age

patients were accepted as cases of acute rheumatic fever, fulfilling the criteria. In the same period 140 patients were referred as rheumatic fever but rejected from the series. Analysis of the final diagnosis in this group of 140 patients is shown in Table III. Fifty-eight $(38 \%)$ were considered to have acute rheumatism but had to be rejected from this series, usually because the arthralgia was confined to one joint or had settled before admission to hospital.

TABLE I

CRITERIA FOR DIAGNOSIS OF ACUTE RHEUMATISM ${ }^{1}$

\section{Major Criteria}

\section{Carditis}

(a) Development of an organic murmur

(b) Change of heart size greater than $15 \%$

(c) Pericardial rub or effusion

(d) Congestive cardiac failure in patients under 25 years in absence of other causes

\section{Polyarthritis}

Pain and either limited active movement or tenderness in two or more joints

3 Chorea

4 Subcutaneous nodules

5 Erythema marginatum or annulare

\section{Minor Criteria}

1 Fever

2 E.S.R., not less than $15 \mathrm{~mm}$. in $1 \mathrm{hr}$. (Westergren)

3 Evidence of previous streptococcal infection

(a) Culture with significant $\beta$ haemolytic streptococci

(b) Antistreptolysin $O$ titre of at least 200 units $/ \mathrm{ml}$.

(c) Reliable history of sore throat in four weeks before onset of rheumatic symptoms

4 P.R. interval of 0.20 seconds or more

5 Reliable history of rheumatic fever (as above ) or evidence of preexisting rheumatic heart disease

${ }^{1}$ These are the criteria of Jones (1944) as amended for M.R.C. and American Heart Association combined trial (1955). 
TABLE III

PATIENTS OVER 12 YEARS INVESTIGATED FOR RHEUMATIC FEVER DURING SAME PERIOD BUT NOT SATISFYING THE CRITERIA

No. of Patients

Acute rheumatism

With chronic rheumatic heart disease

With previous rheumatic fever

With erythema nodosum

Others

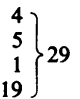

Subacute rheumatism

With chronic rheumatic heart disease

With previous rheumatic fever

Others

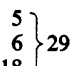

Rheumatoid arthritis

Gonococcal arthritis

Reiter's syndrome

Systemic lupus erythematosus

Erythema nodosum

Henoch-Schönlein syndrome

Serum sickness

Osteomyelitis

Septic arthritis

Arthralgia or arthritis of uncertain cause

Osteoarthritis

Gout

Respiratory infection with arthralgia

Acute pericarditis

Miscellaneous

Total

Observation of this group suggests that many attacks of acute rheumatism cause so little arthralgia that a few aspirin tablets settle the discomfort and the patient never sees a physician.

The onset of rheumatoid arthritis may present acutely like rheumatic fever, but this group often have a positive Rose-Waaler test which confirms the correct diagnosis. Similarly the specific serological test for gonococcal arthritis and the L.E. cell test for disseminated lupus erythematosus help to establish the correct diagnosis. Erythema nodosum with a low antistreptolysin $O$ titre should suggest sarcoidosis.

\section{RHEUMATIC CARDITIS}

When we consider the incidence of carditis in the 139 adolescents or young adults accepted for this series,

\section{TABLE IV}

REPORTED INCIDENCE OF CARDITIS IN ACUTE RHEUMATISM

\begin{tabular}{ll} 
Series & Incidence (\%) \\
\hline Jones and Bland (1952) & 65 \\
Co-operative clinical trial (1955) & 51 \\
Lieber and Holoubek (1956) & 56 \\
U.S. Army (Bates, 1958) & 56 \\
British Army (Slater and Rosenbaum, 1959) & 16 (E.C.G. 31\%) \\
R.A.F. (Malpas and Landon, 1960) & 52 \\
Bywaters and Thomas (1961) & 46 \\
Begg, Kerr, and Knowles (1962) & 18 (E.C.G. 59\%)
\end{tabular}

$25(18 \%)$ had carditis and there were no deatho. This incidence continues the decline in cardit reported in recently published papers on acufe rheumatism (Table IV) although it is not so obvioư⿱宀 if E.C.G. changes alone are accepted as a manifest席 tion of carditis.

The histological reports on auricular appendages biopsied at operation for mitral valvotomy migfit suggest that more stress is put on even ming changes in the electrocardiogram. Catto, Smith, and Taylor (1952) examined 25 auricular appendages removed at operation for mitral valvotomy, the age range of the patients being 24 to 46 years, and founel that $15(60 \%)$ of the auricular appendages containe Aschoff bodies. Seven of the 15 patients concerned gave no history of rheumatic fever and in the remain der the most recent attack had been 10 yeass previously. None of these patients had any evidenee of acute rheumatism before operation, and in all the Westergren E.S.R. was less than $10 \mathrm{~mm}$. in the first hour. This type of study has been extended bo McKeown (1953), who in 17 necropsies on 92 cas of mitral stenosis has shown that where Aschoff bodies are present in the auricular appendages the were also found in the left ventricle. This raises tids vexed question of the significance of these obseg vations. Most pathologists would accept the Aschoff body as a manifestation of active rheumatic cardit but Enticknap (1953), for example, feels that this not proven.

Further, there is the interesting syndrome reported by Abrahams and Brigden (1961) from Nigeri where rheumatic fever is rare, of mitral incompe tence, pulmonary hypertension, and endomy cardial fibrosis. At necropsy in some of these cases Aschoff bodies were observed in the myocardiun Meantime, the pathologist should not put too much stress on the clinicians' inability to detect acti carditis in such cases.

The recent observations of Kaplan and Meyeseria (1962) of an immunological reaction between groug A streptococcal cells and the myofibrils of human heart tissue in a young patient dying of acute rhe matic fever is consistent with an autoimmune carditis and raises the question of the part playe by the Aschoff body in such a process.

\section{ARTHRALGIA}

Polyarthritis was the presenting symptom in $92 \%$ of the cases in this series and in six cases was associated with erythema nodosum.

\section{LABORATORY INVESTIGATIONS}

The erythrocyte sedimentation rate is the mos sensitive measure of the degree of rheumatic activity

傮


available. In this series the E.S.R. (Westergren) had fallen to less than $10 \mathrm{~mm}$. in the first hour in $88 \%$ of patients within eight weeks of treatment. Patients appear to be discharged from hospital with a lower E.S.R. than in the pre-antibiotic era, but in some instances this is due to more accurate diagnosis.

In this series acute rheumatic fever confirmed the seasonal peak in January and appears to be related to the incidence of streptococcal sore throats. We cultured group A, $\beta$ haemolytic streptococci in $33 \%$ of 139 cases, which is high considering that most patients had received penicillin before admission to hospital. The antistreptolysin $O$ titre was above 200 units in $70 \%$ of patients and in all cases associated with erythema nodosum was 1,250 units or more. The antistreptolysin $\mathrm{O}$ titre often takes six months or longer to fall below 200 units and this delay may be related to high dosage of penicillin (Carter, Bywaters, and Thomas, 1962). The titre can be raised in a case of mitral stenosis, presenting first with auricular fibrillation of recent onset and suggesting that active rheumatic carditis is present.

\section{TREATMENT AND PROPHYLAXIS}

With two exceptions, all patients in this series were treated with salicylate and penicillin. The response of the arthralgia to aspirin in moderate dosage (blood level $30 \mathrm{mg}$. per $100 \mathrm{ml}$.) is swift and impressive, but the decline in the development of permanent carditis in the patient with acute rheumatism is due to the negligible recurrence rate today. This is the most significant change in rheumatic fever and would appear to be due to the correct use of penicillin. We have maintained all our cases on oral penicillin $\mathrm{V}$, $125 \mathrm{mg}$. b.d., for three to five years, and have had no recurrence in any patient who remained on this régime.
The long-term use of penicillin in patients with rheumatic fever with established valvular disease of the heart raises special problems, as the Streptococcus viridans about their teeth will be penicillinresistant. Any dental manipulation without a change in antibiotic exposes these patients to the risk of subacute bacterial endocarditis. We have seen several instances of this sequence of events in Glasgow and it has been fully reported by Garrod and Waterworth (1962). These patients must be warned to have a change of antibiotic to cover any period of dental treatment.

\section{CONCLUSION}

The patient is fortunate if the onset of rheumatic carditis is associated with arthralgia and he sees his physician before valvular disease is established. The problem today is how to prevent the development of latent carditis which first appears before the physician has established valvular disease of the heart.

\section{REFERENCES}

Abrahams, D., and Brigden, W. (1961). Brit. med. J., 2, 134.

Bates, R. C. (1958). Ann. intern. med., 48, 1017.

Begg, T. B., Kerr, J. W., and Knowles, B. R. (1962). Brit. med. J., 2, 223.

Bywaters, E. G. L., and Thomas, G. T. (1961). Ibid., 1, 1628.

Carter, Mary E., Bywaters, E. G. L., and Thomas, G. T. (1962). Ibid., $1,965$.

Catto, Mary, Smith, E., and Taylor, W. A. (1952). J. Path. Bact., 64, 673.

Co-operative Clinical Trial of A.C.T.H., Cortisone and Aspirin (1955). Brit. med. J., 1, 555. (1960). Ibid., 2, 1033.

Enticknap, J. B. (1953). Brit. Heart J., 15, 37.

Garrod, L. P., and Waterworth, Pamela M. (1962). Ibid., 24, 39.

Jones, T. D. (1944). J. Amer. med. Ass., 126, 481.

-, and Bland, E. F. (1952). In Rheumatic Fever, edited by L. Thomas. Univ. of Minnesota Press, Minneapolis.

Kaplan, M. H., and Meyeserian, Mary (1962). Lancet, 1, 706.

Lieber, S. L., and Holoubek, J. E. (1956). Ann. intern. Med., 45, 118.

Malpas, J. S., and Landon, J. (1960). Ann. rheum. Dis., 19, 262.

McKeown, Florence (1953). Brit. Heart J., 15, 4, 433.

Slater, J. D. H., and Rosenbaum, S. (1959). Ann. rheum. Dis., 18, 285. 